\title{
Replacement of the ascending aorta in children: A series of fourteen patients
}

\author{
T. Abdel Massih, MD, P. R. Vouhé, MD, P. Mauriat, MD, E. Mousseaux, MD, D. Sidi, MD, and D. Bonnet, MD, \\ Paris, France
}

A ortic root dilatation is mainly observed in children with various connective tissue disorders. The most frequent cause of aortic root dilatation is infantile Marfan syndrome. ${ }^{1}$ Aortic root dilatation has also been recognized as being associated with bicuspid aortic valves, with or without coarctation. ${ }^{2}$ The isolated forms are rare. ${ }^{3}$ This dilatation may be worrisome, because it can lead to aortic insufficiency or dissection. Here we report a series of 14 children who underwent ascending aorta replacement.

\section{Patients, Methods, and Results}

Fourteen children and adolescents (median 6 years, range 1-16.5 years; Table 1) underwent reconstruction of the ascending aorta

From the Service de Cardiologie Pédiatrique et de Chirurgie Cardiaque Pédiatrique, Hôpital Necker-Enfants Malades, Paris, France.

Received for publication Jan 24, 2002; accepted for publication Feb 10, 2002.

Address for reprints: Damien Bonnet, MD, Service de Cardiologie Pédiatrique, Hôpital Necker-Enfants Malades, 149, rue de Sèvres 75743 Paris Cedex 15, France (E-mail: damien.bonnet@nck.ap-hop-paris.fr).

J Thorac Cardiovasc Surg 2002;124:411-3

Copyright (C) 2002 by The American Association for Thoracic Surgery

$0022-5223 / 2002 \$ 35.00+0 \quad \mathbf{1 2 / 5 4 / 1 2 3 7 0 6}$

doi:10.1067/mtc.2002.123706 with mechanical replacement of the aortic valve in 5 cases (Bentall procedure) and with preservation of native aortic valve in 9 cases (Yacoub procedure; Table 2). Three had undergone previous operations. Indication for the elective ascending aorta replacement was either major dilatation of the aorta or rapid progression of the aortic diameter. The mean ascending aortic diameter at surgery was $46.5 \mathrm{~mm}(27-63 \mathrm{~mm})$, and the median rate of progression of the aortic root diameter was $7.5 \mathrm{~mm}$ during the year preceding the aortic replacement (range $2-26 \mathrm{~mm}$ ). The Bentall procedure was chosen in advance in 4 of 5 cases because significant aortic insufficiency was already present. In the last of the 5 cases (patient 8), the decision to replace the aortic valve was taken during the procedure because the valve appeared too altered to be preserved. One patient with infantile Marfan syndrome (patient 2) died 2 days after the operation of massive mitral regurgitation after an attempted mitral valve replacement. Four patients underwent additional concomitant procedures. Four patients required reoperation. Thirteen patients were alive at last follow-up (mean $4.7 \pm 1.2$ years, range 1.5-6.5 years) without symptoms.

\section{Discussion}

Surgery in children with dilatation of the ascending aorta or aortic root can be a challenge. Aortic replacement should be recommended to prevent rupture or dissection. In addition, aortic root replacement with aortic valve sparing is attractive for children who have a normally functioning aortic valve because it may avoid

TABLE 1. Patient characteristics

\begin{tabular}{llcccc}
\hline Case & Associated syndrome or lesions & $\begin{array}{c}\text { Age at } \\
\text { operation } \\
(\mathbf{y})\end{array}$ & $\begin{array}{c}\text { Aortic diameter } \\
\text { at operation } \\
(\mathbf{m m})\end{array}$ & $\begin{array}{c}\text { Rate of } \\
\text { progression* } \\
(\mathbf{m m})\end{array}$ & $\begin{array}{c}\text { Previous procedures } \\
\text { insufficiencyt }\end{array}$ \\
\hline 1 & Marfan syndrome & 1 & 30 & 13 & None \\
2 & Marfan syndrome & 1.5 & 52 & 26 & None \\
3 & Aortic valve dysplasia & 2 & 50 & 6 & None \\
4 & Marfan syndrome & 4 & 42 & 10 & None \\
5 & Marfan syndrome & 4 & 51 & 5 & None \\
6 & Megadolichoaorta & 5 & 43 & 4.6 & Ross \\
7 & Bicuspid aortic valve & 6 & 27 & 9.5 & None \\
8 & Marfan syndrome & 7 & 62 & 10 & None \\
9 & Coarctation of aorta and bicuspid & 10 & 50 & 9 & None \\
& $\quad$ aortic valve & 12 & 41 & 4 & 1 \\
10 & Turner syndrome & 12 & 47 & 8.5 & Pulmonary artery aneurysm \\
11 & Ehlers-Danlos syndrome type III & 16 & 40 & 4 & Coarctation repair \\
12 & Coarctation of aorta & 16.5 & 63 & 4.5 & None \\
13 & Bicuspid aortic valve & 16.5 & 53 & 6 & None \\
14 & Marfan syndrome & & & 1 \\
\end{tabular}

* Rate of progression is the increase in diameter during the year that preceded the aortic replacement.

†Scale ranges from 0 (none) to 3 (extreme). 
TABLE 2. Ascending aorta replacement, additional procedures, and follow-up

\begin{tabular}{|c|c|c|c|c|c|}
\hline Case & Procedure & Additional procedures & Subsequent procedures & $\begin{array}{l}\text { Follow-up } \\
\text { (y) }\end{array}$ & $\begin{array}{c}\text { Aortic } \\
\text { insufficiency* }\end{array}$ \\
\hline 1 & Yacoub & None & $\begin{array}{l}\text { Mitral and tricuspid valve } \\
\text { replacements }(2 \mathrm{y})\end{array}$ & 4 & 1 \\
\hline 2 & $\begin{array}{l}\text { Bentall } \\
\text { (CarboMedics } † \\
16 \mathrm{~mm} \text { ) }\end{array}$ & None & $\begin{array}{l}\text { Mitral valve replacement ( } 2 \mathrm{~d} \\
\text { after Yacoub procedure) }\end{array}$ & Died & 0 \\
\hline 3 & $\begin{array}{l}\text { Bentall } \\
\text { (Duromedics } \ddagger \\
16 \mathrm{~mm} \text { ) }\end{array}$ & None & None & 5 & 0 \\
\hline 4 & Yacoub & $\begin{array}{l}\text { Mitral and tricuspid valve } \\
\text { replacements }\end{array}$ & None & 1.5 & 1 \\
\hline 5 & Yacoub & None & $\begin{array}{l}\text { Bentall (St Jude Medical§ } 25 \\
\text { mm) and aortic arch } \\
\text { replacement }(8 \mathrm{y})\end{array}$ & 2 & 0 \\
\hline 6 & Yacoub & None & $\begin{array}{l}\text { Bentall (St Jude Medical§ } 25 \\
\text { mm) and aortic arch } \\
\text { replacement ( } 6.5 \mathrm{y})\end{array}$ & 1.5 & 0 \\
\hline 7 & $\begin{array}{l}\text { Bentall } \\
\text { (CarboMedics } † \\
21 \mathrm{~mm} \text { ) }\end{array}$ & None & None & 5.5 & 0 \\
\hline 8 & $\begin{array}{l}\text { Bentall (St Jude } \\
\text { Medical§ } 25 \\
\text { mm) }\end{array}$ & None & None & 6.5 & 0 \\
\hline 9 & Yacoub & Coarctation repair & None & 6 & 0 \\
\hline 10 & Yacoub & None & None & 3 & 1 \\
\hline 11 & Yacoub & None & None & 2.5 & 1 \\
\hline 12 & $\begin{array}{l}\text { Bentall } \\
\text { (CarboMedics } † \\
25 \mathrm{~mm} \text { ) }\end{array}$ & None & None & 4 & 0 \\
\hline 13 & Yacoub & $\begin{array}{l}\text { Aortic valve } \\
\text { commissurotomy }\end{array}$ & None & 3.5 & 2 \\
\hline 14 & Yacoub & None & $\begin{array}{l}\text { Bentall (St Jude Medical§ } 25 \\
\text { mm, } 19 \text { y) }\end{array}$ & 6 & 0 \\
\hline
\end{tabular}

*Scale ranges from 0 (none) to 3 (extreme).

tCarboMedics, Inc, Austin, Tex.

$\ddagger$ Hemex Scientific Inc, Austin, Tex.

$\S$ St Jude Medical Inc, Minneapolis, Minn.

anticoagulation. The timing of surgery therefore has to take into account the aortic diameter, the rate of progression of the dilatation, the function of the aortic valve, and the potential deterioration of valve function according to the known natural history of a given connective tissue defect. Even all this information may not be sufficient, because the risk of reoperation has also to be considered. In our series, 2 patients with Marfan syndrome (patients 5 and 14) had to undergo aortic valve replacement for aortic insufficiency 3 years after a Yacoub procedure. Patient 1, who had severe neonatal Marfan syndrome, already had important mitral and tricuspid valves prolapses at the time of the Yacoub procedure, but there was no regurgitation. A few months later, this patient had to be reoperated on for symptomatic mitral valve regurgitation. Patient 2 was similar and died after the operation of massive mitral regurgitation. Because of these cases, the third patient with neonatal Marfan syndrome and mitral valve prolapse (patient 4) underwent both procedures simultaneously while there was a trivial mitral regurgitation. Finally, the patient with megadolichoaorta (patient 6) had an aneurysm develop in the horizontal aorta above the conduit placed during the Yacoub procedure. He had moderate, asymptomatic aortic regurgitation, but we decided to replace the aortic valve during the reoperation to avoid a third procedure.

With respect to the aortic diameter, we followed the recommendations established for Marfan syndrome. ${ }^{4}$ We subjected patients to prophylactic surgery when the aortic diameter was larger than $50 \mathrm{~mm}$ or when the progression of the dilatation was rapid, regardless of age. The patient with Turner syndrome (patient 10) had a moderate dilatation of the aorta with a rate of progression of $4 \mathrm{~mm} / \mathrm{y}$, but she was hypertensive and wanted to receive estrogens and progesterone to initiate puberty. Because of the high risk of dissection in this condition, ${ }^{5}$ she was operated on even though the absolute value of her aortic diameter was relatively low relative to standard recommendations for prophylactic interventions.

It is difficult to draw conclusions from short series. In our experience, replacement of the ascending aorta in children has a low operative risk but a high reoperation rate. Reoperation could 
be avoided in cases of neonatal Marfan syndrome by repairing significant mitral valve prolapse during the same procedure. Worsening of aortic regurgitation occurs in Marfan syndrome after the Yacoub procedure, which raises the question of prophylactic aortic valve replacement as a primary procedure in this condition.

\section{References}

1. Dervanian P, Mace L, Folliguet TA, Di Virgilio A. Surgical treatment of aortic root aneurysm related to Marfan syndrome in early childhood. Pediatr Cardiol. 1998;19:369-73.
2. Bonderman D, Gharehbaghi-Schnell E, Wollenek G, Maurer G, Baumgartner H, Lang IM. Mechanisms underlying aortic dilatation in congenital aortic valve malformation. Circulation. 1999;99:2138-43.

3. Pfammatter JP, Pavlovic M, Berdat P, Carrel T. Dilation of the ascending aorta in childhood: 4 cases without obvious predisposing disease. Cardiol Young. 2001;11:169-72.

4. Gott VL, Greene PS, Alejo DE, Cameron DE, Naftel DC, Miller DC, et al. Replacement of the aortic root in patients with Marfan's syndrome. N Engl J Med. 1999;340:1307-13.

5. Lin AE, Lippe B, Rosenfeld RG. Further delineation of aortic dilation, dissection, and rupture in patients with Turner syndrome. Pediatrics. 1998;102:e12. 